\title{
Dams on Mekong tributaries as significant contributors of hydrological alterations to the Tonle Sap Floodplain in Cambodia
}

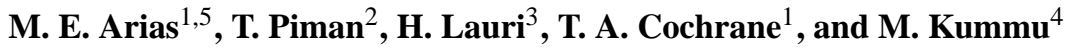 \\ ${ }^{1}$ Department of Civil and Natural Resources Engineering, University of Canterbury, Christchurch, New Zealand \\ ${ }^{2}$ Mekong River Commission, Vientiane, Laos \\ ${ }^{3}$ EIA Finland Ltd, Espoo, Finland \\ ${ }^{4}$ Water \& Development Research Group, Aalto University, Espoo, Finland \\ ${ }^{5}$ Sustainability Science Program, Harvard University, Cambridge, USA \\ Correspondence to: T. A. Cochrane (tom.cochrane@ canterbury.ac.nz)
}

Received: 24 January 2014 - Published in Hydrol. Earth Syst. Sci. Discuss.: 18 February 2014

Revised: - - Accepted: 17 October 2014 - Published: 18 December 2014

\begin{abstract}
River tributaries have a key role in the biophysical functioning of the Mekong Basin. Of particular interest are the Sesan, Srepok, and Sekong (3S) rivers, which contribute nearly a quarter of the total Mekong discharge. Forty two dams are proposed in the $3 \mathrm{~S}$, and once completed they will exceed the active storage of China's large dam cascade in the Upper Mekong. Given their proximity to the Lower Mekong floodplains, the 3S dams could alter the flood-pulse hydrology driving the productivity of downstream ecosystems. Therefore, the main objective of this study was to quantify how hydropower development in the $3 \mathrm{~S}$, together with definite future (DF) plans for infrastructure development through the basin, would alter the hydrology of the Tonle Sap's Floodplain, the largest wetland in the Mekong and home to one of the most productive inland fisheries in the world. We coupled results from four numerical models representing the basin's surface hydrology, water resources development, and floodplain hydrodynamics. The scale of alterations caused by hydropower in the $3 \mathrm{~S}$ was compared with the basin's DF scenario driven by the Upper Mekong dam cascade. The DF or the 3S development scenarios could independently increase Tonle Sap's 30-day minimum water levels by $30 \pm 5 \mathrm{~cm}$ and decrease annual water level fall rates by $0.30 \pm 0.05 \mathrm{~cm} \mathrm{day}^{-1}$. When analyzed together $(\mathrm{DF}+3 \mathrm{~S})$, these scenarios are likely to eliminate all baseline conditions (1986-2000) of extreme low water levels, a particularly important component of Tonle Sap's environmental flows. Given the ongoing trends and large economic incentives in the hydropower business in the region,
\end{abstract}

there is a high possibility that most of the $3 \mathrm{~S}$ hydropower potential will be exploited and that dams will be built even in locations where there is a high risk of ecological disruption. Hence, retrofitting current designs and operations to promote sustainable hydropower practices that optimize multiple river services - rather than just maximize hydropower generation - appear to be the most feasible alternative to mitigate hydropower-related disruptions in the Mekong.

\section{Introduction}

More than half of the world's greatest rivers have been altered by dams (Nilsson et al., 2005) and there is worldwide evidence showing that hydropower development causes significant hydrological and ecological disruptions to downstream freshwater ecosystems (Poff and Zimmermann, 2010). Understanding the cumulative impact of water resources infrastructure is important for sustainable development of river basins, and although hydrological alterations from dams have basin-wide implications, impact assessments typically concentrate on river segments directly upstream and downstream of single dam projects (Nilsson and Berggren, 2000). Impact assessments, however, become more challenging when critical ecosystems occur further downstream under the influence of multiple dams as well as other water infrastructure components (e.g., irrigation, water supply, and flood control). The situation becomes even more complex in large rivers where the interests of upstream 


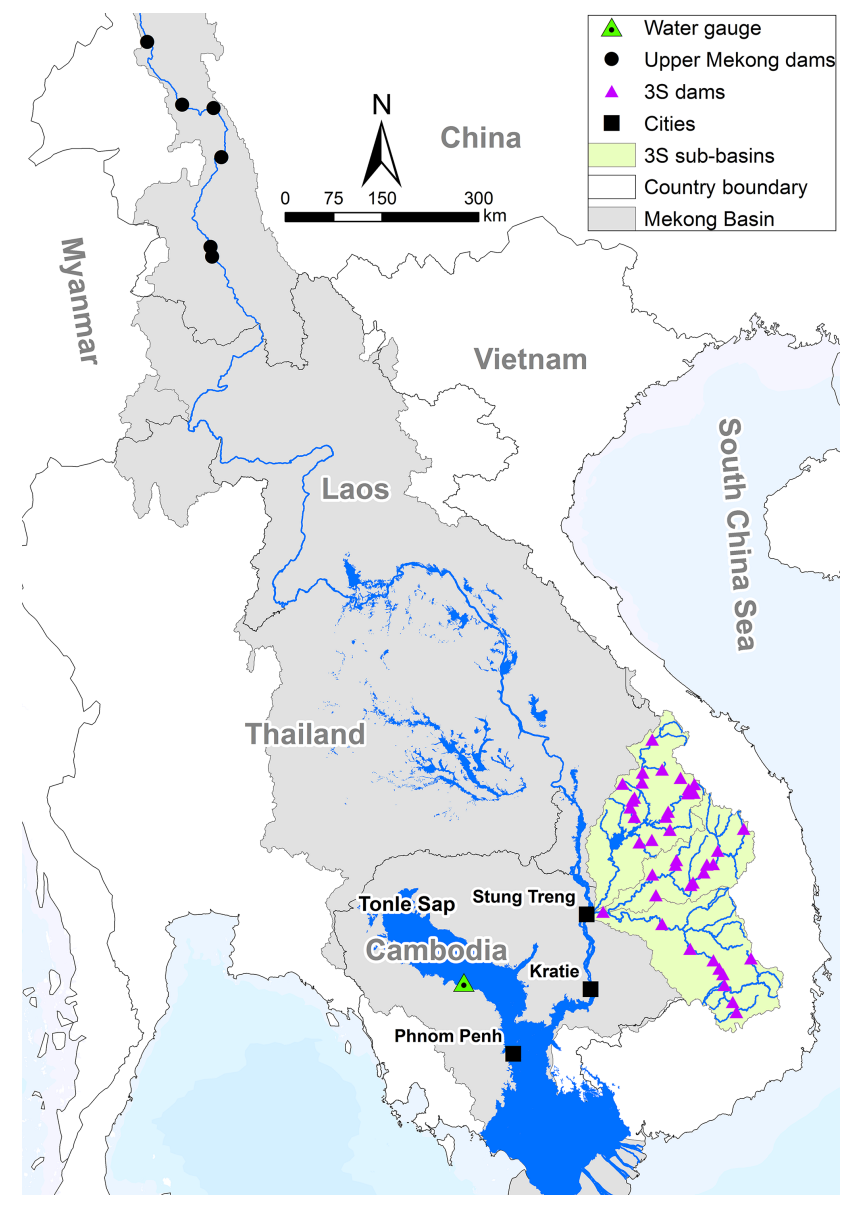

Figure 1. Map of the Mekong Basin highlighting its floodplains and dams in the definite future (black dots) and $3 \mathrm{~S}$ development scenarios (violet triangles). The green triangle shows the Kampong Luong water level gauge location on the Tonle Sap.

stakeholders differ from those downstream. Such is the case of the Mekong, a transboundary basin with historically low levels of hydrological regulation (i.e., the fraction of the annual water discharge that can be stored in reservoirs) comparable to other large tropical basins such as the Amazon and the Congo (Lehner et al., 2011; Nilsson et al., 2005). Aggressive plans for multiple large hydropower schemes throughout the Mekong Basin for economic development are expected to bring significant disruptions to the hydrological regime (Lauri et al., 2012; Piman et al., 2013b), compromising the geomorphology (Kummu et al., 2010; Walling, 2009), fish ecology (Ziv et al., 2012), and productivity of the downstream floodplain ecosystems (Arias et al., 2014) that sustain the food security of millions of people.

The Mekong is the largest river and basin in Southeast Asia, covering $795000 \mathrm{~km}^{2}$ shared by six different countries: China, Myanmar (Burma), Thailand, Laos, Cambodia, and Vietnam (Fig. 1). Mean annual discharge in the Mekong at Kratie in Cambodia is $475 \mathrm{~km}^{3}$ year $^{-1}$ or $14500 \mathrm{~m}^{3} \mathrm{~s}^{-1}$, varying from an average of less than $3000 \mathrm{~m}^{3} \mathrm{~s}^{-1}$ dur- ing March-April, to nearly $40000 \mathrm{~m}^{3} \mathrm{~s}^{-1}$ during AugustSeptember (Adamson et al., 2009). The Sesan, Srepok, and Sekong river basins (collectively known as the $3 \mathrm{~S}$ ) cover an area of $78650 \mathrm{~km}^{2}$ distributed among Cambodia (33\%), Laos (29\%), and Vietnam (38\%). Due to its relatively high rainfall precipitation $\left(1100-3800 \mathrm{~mm}\right.$ year $\left.{ }^{-1}\right)$, the $3 \mathrm{~S}$ provides the largest flow contribution among Mekong tributaries, with an average discharge of $510 \mathrm{~m}^{3} \mathrm{~s}^{-1}$ during March-April and $6133 \mathrm{~m}^{3} \mathrm{~s}^{-1}$ during September. In general, the $3 \mathrm{~S}$ contributes $23 \%$ of the annual Mekong discharge, compared to $16 \%$ generated in the Upper Mekong in China (Adamson et al., 2009).

The Mekong meets the Tonle Sap system $300 \mathrm{~km}$ downstream from Stung Treng at the Cambodian capital, Phnom Penh. From October to May, water flows from the Tonle Sap to the Mekong at a maximum daily discharge rate of $8300 \mathrm{~m}^{3} \mathrm{~s}^{-1}$; when the wet monsoon reaches the basin in May, the Mekong River rises to a higher level than the Tonle Sap, forcing the latter to reverse its flow towards its lake. This phenomenon creates a floodplain that extends over $15000 \mathrm{~km}^{2}$ and stores up to $76.1 \mathrm{~km}^{3}$ of Mekong's annual flood-pulse (Kummu et al., 2014). Overall, $53.5 \%$ of the water entering the Tonle Sap system comes from the Mekong, $34 \%$ from 11 river tributaries, and $12.5 \%$ directly from rainfall (Kummu et al., 2014).

Hydropower development in the Mekong is occurring in three distinct regions. The first is the Lancang Jiang cascade in the Upper Mekong River in China (Fig. 1), a series of 6 dams ( 5 already built) with downstream hydrological alterations expected as far down as Kratie (Räsänen et al., 2012). The second focus of development is a series of 11 dams along the mainstream channel in the Lower Mekong, only one of which is under construction, the Xayaburi Dam in Laos. The Lower Mekong mainstream dams have become very controversial due to their potential impacts on fisheries (Ziv et al., 2012) and their role in political affairs among the basin's countries (Grumbine et al., 2012; Grumbine and Xu, 2011; Stone, 2011). Of greater concern in terms of hydrological alterations is the third region of development occurring in the Mekong tributaries, in particular the 3S, where at least 42 dams are at some stage of development without much regional coordination or stakeholder consultation. Because of its proximity to the Tonle Sap and the rest of the Lower Mekong floodplains, flow regulation in the $3 \mathrm{~S}$ will most likely affect the floodplain's hydrological seasonality. Should the Tonle Sap hydrology be altered, there could be serious consequences for the ecological productivity supported by its floodplain (Arias et al., 2014).

Thus far, existing dams are believed to have caused very little hydrological alteration in the Lower Mekong (Adamson et al., 2009). There have been alterations to the frequency of extreme events beginning in the mid-1970s, but this is probably linked to changes in the El Niño-Southern Oscillation (Delgado et al., 2012; Räsänen and Kummu, 2013). Several research efforts and modeling tools have been developed to 
evaluate ongoing and future hydrological alterations in the Mekong (Johnston and Kummu, 2011). The primary focus of these studies has been the cumulative impact of multiple water infrastructure development plans for the basin (Lauri et al., 2012; Piman et al., 2013b; WB, 2004). Other studies have scrutinized alterations in particular regions of development, such as the dam cascade in the Upper Mekong River (Räsänen et al., 2012) and the 3S (Piman et al., 2013a; Ty et al., 2011), but links between development in these regions and impacts on the Lower Mekong floodplains have not been assessed. Impact assessments of basin-wide alterations to the Tonle Sap, however, do exist and provide a good understanding of the general trends of future changes in the floodplain. Kummu and Sarkkula (2008) initially argued that the upstream development scenario from a World Bank report (WB 2004) could increase the Tonle Sap's dry season water levels by $15 \mathrm{~cm}$ and decrease wet season water levels by $36 \mathrm{~cm}$, leading to a large reduction of seasonally inundated areas. Arias et al. $(2012,2013,2014)$ demonstrated that hydropower-related alterations to the Tonle Sap's hydrology could cause major disruptions to existing floodplain habitats and their contribution to aquatic primary production.

Impacts of hydrological alterations in rivers and floodplains have been well documented for decades (Petts, 1980). Hundreds of studies provide evidence that hydrological alterations cause ecological disruptions in river and riparian systems (Poff and Zimmermann, 2010), but most of these studies have been carried out in single river reaches in North America and Europe, where more than three-quarters of river discharges are regulated (Dynesius and Nilsson, 1994), and where sufficient time series exist for statistical inference of pre- and post-dam alterations (FitzHugh, 2014; Poff et al., 2007). Studies in these regions have evaluated impacts of dam development based on the scale of alterations to the magnitude, frequency, duration, timing, and rate of change of natural flow regimes required for the integrity of river and floodplain ecosystems (Poff et al., 1997). Based on these properties, a method to assess the impacts of hydrological alternations (IHAs) to environmental flows was developed (Richter et al., 1996, 1997). This method defines 32 hydrological parameters and environmental flow components (EFCs) and assesses the magnitude and statistical significance of alterations caused by flow regulation. Recent developments have been proposed to the IHA method, including the analysis of multivariate components among indicators of alterations (Gao et al., 2009) and ranking of alteration levels for specific EFCs (FitzHugh, 2014).

Most of the current construction of hydropower projects is happening in the (sub-) tropics in South America, Africa and Asia (Kareiva, 2012), where hydrological and ecological monitoring has not been carried out to the required temporal span and resolution to comprehensively use the IHA method. (It typically requires time series with at least 20 years of daily measurements; The Nature Conservancy, 2009). Perhaps the only exceptions to this regional limitation are the Murray-
Darling Basin in Australia (Kingsford, 2000) and the Paraná River in Brazil (Agostinho et al., 2009), where hydrological alterations and corresponding ecological disruptions have been well documented. Despite the obvious limitations, applying the IHA method to tropical rivers under development brings interesting challenges and benefits. First, IHA can be used as an a priori impact assessment tool applied to simulated scenarios of hydropower development in order to plan optimal and sustainable dam locations and operations. Furthermore, the tool can be used to compare the level of alterations between different projects and/or cascades, thus helping prioritize where sustainable hydropower and basin management strategies are most needed. Moreover, the IHA tool could be used to evaluate the cumulative impacts of dam cascades at critical downstream river reaches and high-value ecosystems, instead of just focusing on nearby downstream impacts of a single dam. With these particular applications in mind, an assessment of hydrological alterations in the Mekong would be an informative case study not only for researchers and managers in the basin but also to others managing (sub-)tropical rivers undergoing similar development and biophysical transitions.

The main objective of this study is to quantify how the proposed hydropower dams in the tributaries of the Lower Mekong, together with the definite future (DF) plans for infrastructure development throughout the basin, would alter the hydrology of the Tonle Sap's floodplain. This was carried out by first validating a 2-D hydrodynamic model of the Lower Mekong floodplains with historical water levels at the Tonle Sap. We then compared the expected hydrological alterations caused by scenarios of $3 \mathrm{~S}$ hydropower development and the most likely development (i.e., DF) scenario for the rest of the Mekong Basin by 2015. Once these two scenarios were analyzed separately, their cumulative impact on hydrological parameters and environmental flows at the Tonle Sap's floodplain were estimated. We conclude with a discussion of the major implications of our findings as well as feasible alternatives to mitigate the expected hydrological alteration and consequent ecological disruptions.

\section{Methods}

\subsection{Modeling approach}

This study integrates the results of four different sets of numerical models (Fig. 2). Basin hydrology and daily runoff flows were simulated in a daily time step using the Soil and Water Assessment Tool (SWAT) as described by Piman et al. (2013a). This SWAT model was calibrated for 28 different gauges upstream of Kratie. Sub-basin runoff flows were then used as inputs for two different models of development impacts on water resources. The first set of results came from simulations using the Integrated Quantity and Quality Model (IQQM) that Piman et al. (2013b) applied to assess the im- 


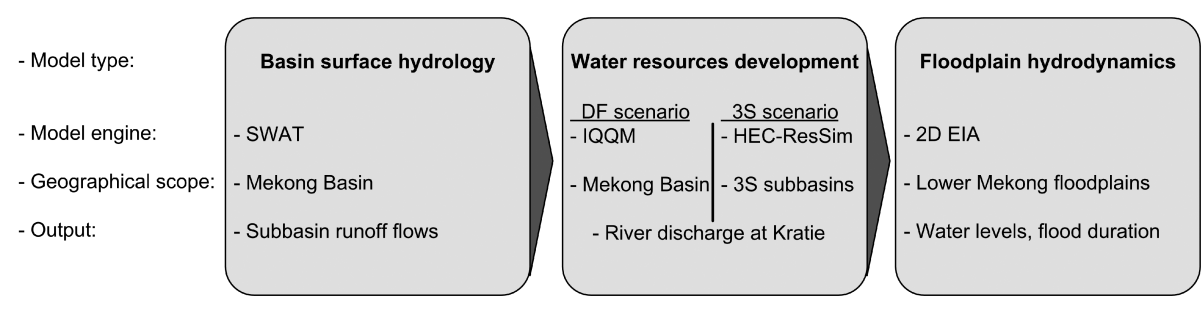

Figure 2. Models used and their general features. DF is definite future.

pact of water regulation and abstraction in the Mekong. The second set of results were generated with the HEC-ResSim model presented by Piman et al. (2013a), which simulated the impact of hydropower development and operations in the 3S. Results from both IQQM and HEC-ResSim were used to compute daily river discharges in the Mekong at Kratie south of the 3S confluence (see location in Fig. 1). Water movement from this location down through the Lower Mekong floodplains (including the Tonle Sap) was simulated with the two dimensional Environmental Impact Assessment Model (2-D EIA), a hydrodynamic model that numerically solves the simplified Navier-Stokes and continuity equations using a finite difference method (Koponen et al., 2010). The 2-D EIA Lower Mekong application covers an area of $430 \mathrm{~km}$ by $570 \mathrm{~km}$ from Kratie to the Mekong Delta at a grid resolution of $1 \mathrm{~km}^{2}$. An earlier version of this application was presented by Västilä et al. (2010). Daily water levels from the 2-D EIA model were extracted and validated at Kampong Luong, where the main water gauge on the Tonle Sap's lake is located (see Fig. 1). Simulated water levels were validated against historical measurements for the entire simulation period (1986-2000). Validation results were evaluated according to the linear correlation coefficient $(r)$ between observed and simulated results, as well as the Nash-Sutcliffe efficiency coefficient (Nash and Sutcliffe, 1970).

\subsection{Modeling scenarios}

A total of four scenarios were considered for this study (Table 1). A baseline scenario (BL) represented recent historical conditions (1986-2000) before major hydropower projects were built in the Upper Mekong and the 3S. We were limited to this 15-year time series because no continuous and reliable water level data exist for the Tonle Sap before this period, and because building of large dams began after 2000 . Two of the wettest and five of the driest years in the past seven centuries occurred during this baseline period (Räsänen et al., 2013), and it was therefore considered a good representation of the range of historical hydrological conditions and variability in the basin. Although 17 dams were already operational by the end of this period (including the Manwan dam in China built in 1993), they were generally small and only accounted for $9.1 \mathrm{~km}^{3}$ of active storage, in contrast to the approximately $38 \mathrm{~km}^{3}$ that have been built since the year
2000 (MRC, 2009). The first scenario of water resource development that was analyzed resembles the definite future (DF) scenario proposed by the Mekong River Commission (MRC; Piman et al., 2013b), which represents existing and on-going water resources infrastructure development up to 2015. The DF scenario is primarily driven by the six dams in the Lancang Jiang dam cascade in the Upper Mekong in China, which provide an additional $23.2 \mathrm{~km}^{3}$ of active storage from baseline (Räsänen et al., 2012). The DF scenario in our study does not consider any proposed dams in the 3S. The second scenario of water resource development was based on the simulations of dams operations in the $3 \mathrm{~S}$ presented by Piman et al. (2013a). This scenario represents a total of 42 dams at different development stages (existing, under construction, and proposed) in the $3 \mathrm{~S}$ tributaries and sub-tributaries with $26.3 \mathrm{~km}^{3}$ of active storage. The last scenario analyzed represents the cumulative impact of both DF and $3 \mathrm{~S}(\mathrm{DF}+3 \mathrm{~S})$ with an additional $49.5 \mathrm{~km}^{3}$ of active storage from the baseline. All simulations were carried out in daily time steps for a period of 15 years from 1 January 1986 to 31 December 2000.

\subsection{Data analysis}

Simulated water levels were used to calculate 30 hydrological parameters and corresponding alterations using the IHA Tool (The Nature Conservancy 2009). This tool computes hydrologic parameters that are relevant to ecosystem processes and it calculates the level of alteration between the baseline and post-alteration periods. Analyses were carried out by combining the BL scenario time series with each of the water development scenarios so that the first 15 years defined the pre-alteration period and the second 15 years represented the post-development period, as if all dams were built at once on January 1, 2001. Three different sets of analyses were carried out: the DF, $3 \mathrm{~S}$, and combined DF $+3 \mathrm{~S}$ scenarios. All analyses were carried out using non-parametric statistics. Data were analyzed according to calendar years (1 January to 31 December). Environmental flow components were set according to commonly used parameters. The water level 75th percentile for each year was defined as the threshold between periods of low flow and high flow pulses. Small floods were defined as those with a peak above the 2-year return period flood, whereas large flood events were 
Table 1. Description of water infrastructure development scenarios.

\begin{tabular}{lll}
\hline Scenario name & Description & Active storage $\left(\mathrm{km}^{3}\right)$ \\
\hline Baseline (BL) & $\begin{array}{l}\text { Simulated baseline conditions 1986-2000 } \\
\text { (Piman et al., 2013b) }\end{array}$ & 9.1 \\
\hline Definite future (DF) & $\begin{array}{l}\text { Water infrastructure development plans up to 2015, } \\
\text { including 3.4 million ha irrigation areas, water supply } \\
\text { demands, and 6 dams in the Upper Mekong (Piman } \\
\text { et al., 2013b) }\end{array}$ & \\
\hline 3S hydropower development (3S) & $\begin{array}{l}\text { Construction and operation of 42 hydropower and } \\
\text { regulation dams in the main tributaries and sub- }\end{array}$ & 35.4 (additional 26.3 from BL) \\
& $\begin{array}{l}\text { tributaries of the Sesan, Sekong, and Srepok rivers } \\
\text { (Piman et al., 2013a) }\end{array}$ & \\
\hline DF +3S & $\begin{array}{l}\text { Cumulative impact of the DF and 3S scenarios } \\
\text { described above }\end{array}$ & 58.6 (additional 49.5 from BL) \\
\hline
\end{tabular}

defined as those with a peak above the 10-year flood. Extremely low flows were defined as those with an initial low flow below the 10th percentile of the daily records for each period.

Annual summary statistics were used to compare the magnitude of alterations between scenarios. All hydrologic parameters were analyzed with the Kruskal-Wallis test (Kruskal and Wallis, 1952) to determine if differences among the BL, DF, and 3S scenarios were significant at the 95th percentile level. Once individual scenarios were compared, hydrological alterations were calculated for the DF and for the $\mathrm{DF}+3 \mathrm{~S}$ scenarios. Environmental flow components were estimated, exceedance probability charts plotted, and hydrological alteration factors computed for all parameters according to the range of variability approach (RVA; Richter et al. 1997). This approach consists of dividing the data into three different categories (bounded by the 33rd and 67th percentiles), estimating the frequency at which values are expected to occur within each category, and then estimating the percentage difference between the expected frequency and the simulated frequency for the impact scenarios.

In addition to the IHA analysis, changes in spatial flooding patterns were analyzed. Raster images representing cumulative flood duration were generated from the 2-D EIA model throughout the geographical extent of the Tonle Sap's floodplain $\left(15000 \mathrm{~km}^{2}\right.$ approximately). These were transformed into flood frequency rasters by normalizing flood duration according to the simulation's total length. Outputs from the impact scenarios were overlaid on the baseline raster in order to calculate and visualize spatial changes in flood regime.

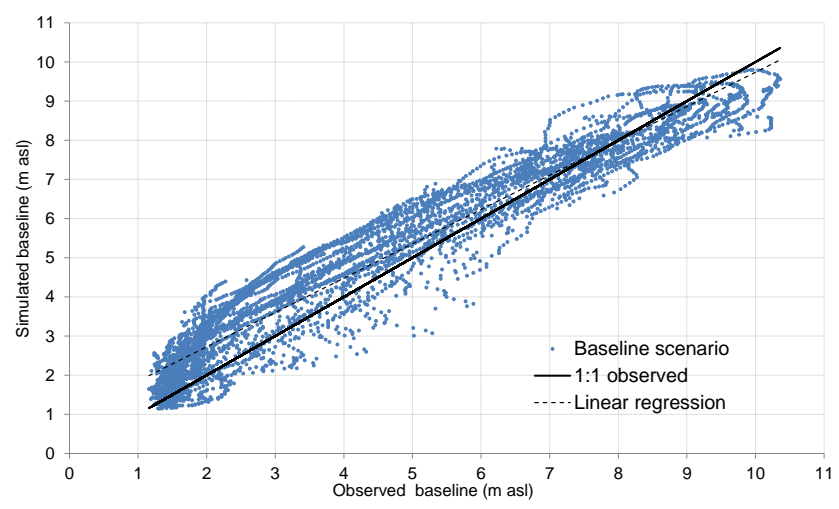

Figure 3. Observed versus projected daily water levels (in meters above sea level, m a.s.1.) during 1986-2000 at Kampong Luong.

\section{Results}

\subsection{Baseline scenario validation}

Prior to the analysis and comparison of scenarios, the simulated daily water levels at Kampong Luong were validated against historical measurements for the entire simulation period (1986-2000). Overall, simulations of the baseline scenario show a tendency to overestimate historical records of daily water levels at low water levels, but this discrepancy disappears at water levels above approximately $7 \mathrm{~m}$ (Fig. 3). The linear correlation coefficient between the observed and simulated daily water levels was 0.97 and the Nash-Sutcliffe efficiency coefficient was 0.91 .

\subsection{Comparison between BL, DF, and 3S scenarios}

Overall, similar scales and alteration trends between the DF and the $3 \mathrm{~S}$ scenarios were found. Of the 30 hydrological parameters analyzed, 9 appeared to be significantly different $(p \leq 0.05)$ in either the DF or the $3 \mathrm{~S}$ scenario when com- 


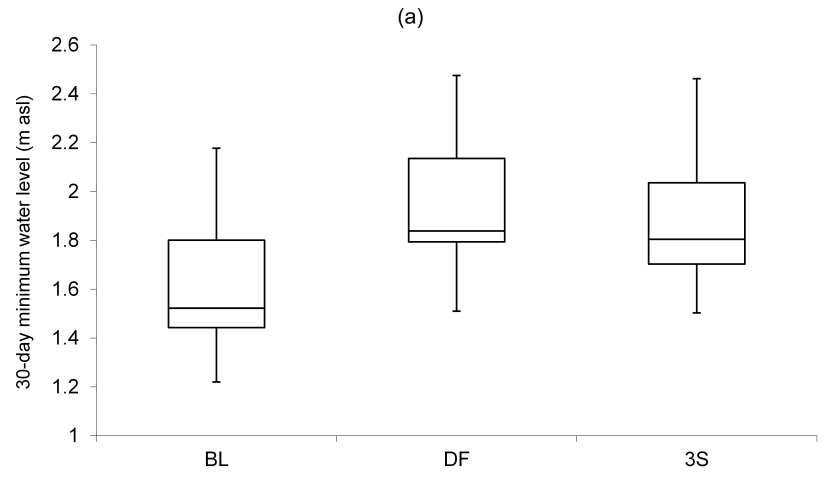

Table 2. Kruskal-Wallis test results for comparison of annual parameters. Each column group represents a one-to-one comparison between the baseline (BL), definite future (DF) and $3 \mathrm{~S}$ hydropower (3S) scenarios. $\chi^{2}$ is the test statistic and $p$ is the probability value of $\chi^{2}$. Significant $p$ values $(\leq 0.05)$ are highlighted in bold.

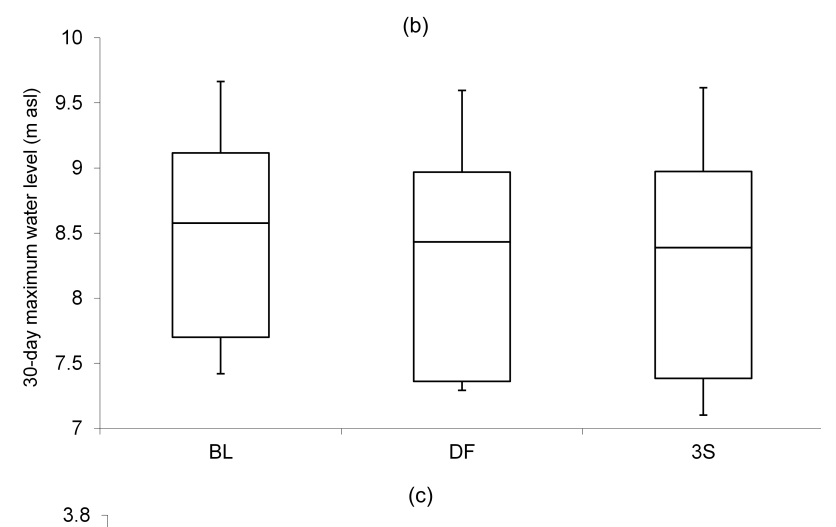

\begin{tabular}{|c|c|c|c|c|c|c|}
\hline \multirow[b]{2}{*}{ Parameters } & \multicolumn{2}{|c|}{ BL-DF } & \multicolumn{2}{|c|}{ BL-3S } & \multicolumn{2}{|c|}{ DF-3S } \\
\hline & $\chi^{2}$ & $p$ & $\chi^{2}$ & $p$ & $\chi^{2}$ & $p$ \\
\hline \multicolumn{7}{|l|}{ Monthly water levels } \\
\hline January & 0.00 & 0.98 & 0.00 & 0.95 & 0.01 & 0.92 \\
\hline February & 0.72 & 0.40 & 0.53 & 0.47 & 0.01 & 0.92 \\
\hline March & 2.55 & 0.11 & 2.42 & 0.12 & 0.02 & 0.90 \\
\hline April & 7.84 & 0.01 & 6.72 & 0.01 & 0.08 & 0.77 \\
\hline May & 8.07 & 0.00 & 6.94 & 0.01 & 0.41 & 0.52 \\
\hline June & 1.93 & 0.16 & 0.95 & 0.33 & 0.59 & 0.44 \\
\hline July & 0.19 & 0.66 & 0.02 & 0.90 & 0.19 & 0.66 \\
\hline August & 0.27 & 0.60 & 0.17 & 0.68 & 0.01 & 0.92 \\
\hline September & 0.80 & 0.37 & 0.47 & 0.49 & 0.07 & 0.79 \\
\hline October & 1.21 & 0.27 & 1.03 & 0.31 & 0.01 & 0.92 \\
\hline November & 0.72 & 0.40 & 0.47 & 0.49 & 0.03 & 0.85 \\
\hline December & 0.41 & 0.52 & 0.23 & 0.63 & 0.08 & 0.77 \\
\hline \multicolumn{7}{|l|}{ Annual parameters } \\
\hline 1-day minimum & 7.84 & 0.01 & 6.72 & 0.01 & 0.62 & 0.43 \\
\hline 3-day minimum & 7.84 & 0.01 & 6.72 & 0.01 & 0.62 & 0.43 \\
\hline 7-day minimum & 7.84 & 0.01 & 6.72 & 0.01 & 0.65 & 0.42 \\
\hline 30-day minimum & 7.50 & 0.01 & 6.09 & 0.01 & 0.59 & 0.44 \\
\hline 90-day minimum & 4.92 & 0.03 & 3.80 & 0.05 & 0.31 & 0.58 \\
\hline 1-day maximum & 1.03 & 0.31 & 0.95 & 0.33 & 0.00 & 1.00 \\
\hline 3-day maximum & 1.03 & 0.31 & 0.95 & 0.33 & 0.00 & 1.00 \\
\hline 7-day maximum & 1.03 & 0.31 & 0.87 & 0.35 & 0.00 & 0.98 \\
\hline 30-day maximum & 0.95 & 0.33 & 0.87 & 0.35 & 0.00 & 0.98 \\
\hline 90-day maximum & 0.95 & 0.33 & 0.95 & 0.33 & 0.08 & 0.77 \\
\hline Date of minimum & 0.29 & 0.59 & 0.07 & 0.79 & 0.14 & 0.71 \\
\hline Date of maximum & 0.04 & 0.85 & 0.00 & 0.98 & 0.04 & 0.85 \\
\hline Base flow index & 18.79 & 0.00 & 17.72 & 0.00 & 1.60 & 0.21 \\
\hline Fall rate & 8.94 & 0.00 & 8.96 & 0.00 & 0.20 & 0.66 \\
\hline Rise rate & 2.69 & 0.10 & 0.65 & 0.42 & 0.80 & 0.37 \\
\hline Low pulse duration & 0.00 & 0.98 & 0.00 & 0.98 & 0.02 & 0.90 \\
\hline High pulse duration & 0.00 & 1.00 & 0.00 & 0.97 & 0.01 & 0.92 \\
\hline Number of reversals & 0.00 & 0.96 & 0.11 & 0.73 & 0.08 & 0.78 \\
\hline
\end{tabular}

Figure 4. Boxplots of (a) 30-day minimum water level, (b) 30-day maximum water level, and (c) water fall/drop rate for the baseline (BL), Definite Future (DF), and 3S hydropower development (3S) scenarios. 30-day minimum and drop rate for both DF and $3 \mathrm{~S}$ are significantly different from BL $(p \leq 0.05)$. Water fall/drop rate refers to the difference between the annual minimum and maximum water levels divided by the duration between them. There are no significant differences in 30-day maximum water level among scenarios.

pared to the BL scenario (Table 2): April and May monthly water levels, water fall rate (that is, the difference between the annual minimum and maximum water levels divided by the duration between them), base flow index (that is, the 7day minimum over the mean annual water level), and 1, 3, 7, 30, and 90-day minima. None of the parameters appeared to be significantly different between the DF and the $3 \mathrm{~S}$ scenarios. Box plots of some of the most representative parameters were prepared in order to demonstrate the general trends en-

countered in this comparison (Fig. 4). For instance, the 30day minimum water level median was $1.52 \mathrm{~m}$ (with a range of $1.22-2.18 \mathrm{~m}$ ) for the BL scenario, which is significantly different from $1.84 \mathrm{~m}(1.51-2.48 \mathrm{~m})$ and $1.80 \mathrm{~m}(1.50-2.46 \mathrm{~m})$ for the DF and $3 \mathrm{~S}$ scenarios, respectively (Fig. 4a). Water level fall rate for the BL (median of $3.2 \mathrm{~cm} \mathrm{day}^{-1}$, range 3.0$3.6 \mathrm{~cm} \mathrm{day}^{-1}$ ) was also significantly different from DF (median of $2.8 \mathrm{~cm} \mathrm{day}^{-1}$, range $2.7-3.4 \mathrm{~cm} \mathrm{day}^{-1}$ ) and $3 \mathrm{~S}$ (median of $2.9 \mathrm{~cm} \mathrm{day}^{-1}$, range $2.7-3.4 \mathrm{~cm} \mathrm{day}^{-1}$; Fig. 4c). In contrast, the maximum annual water level of the BL scenario (median of $8.58 \mathrm{~m}$, range of 7.42-9.67 m) was not found to be significantly different from the other development scenarios (Fig. 4b). 


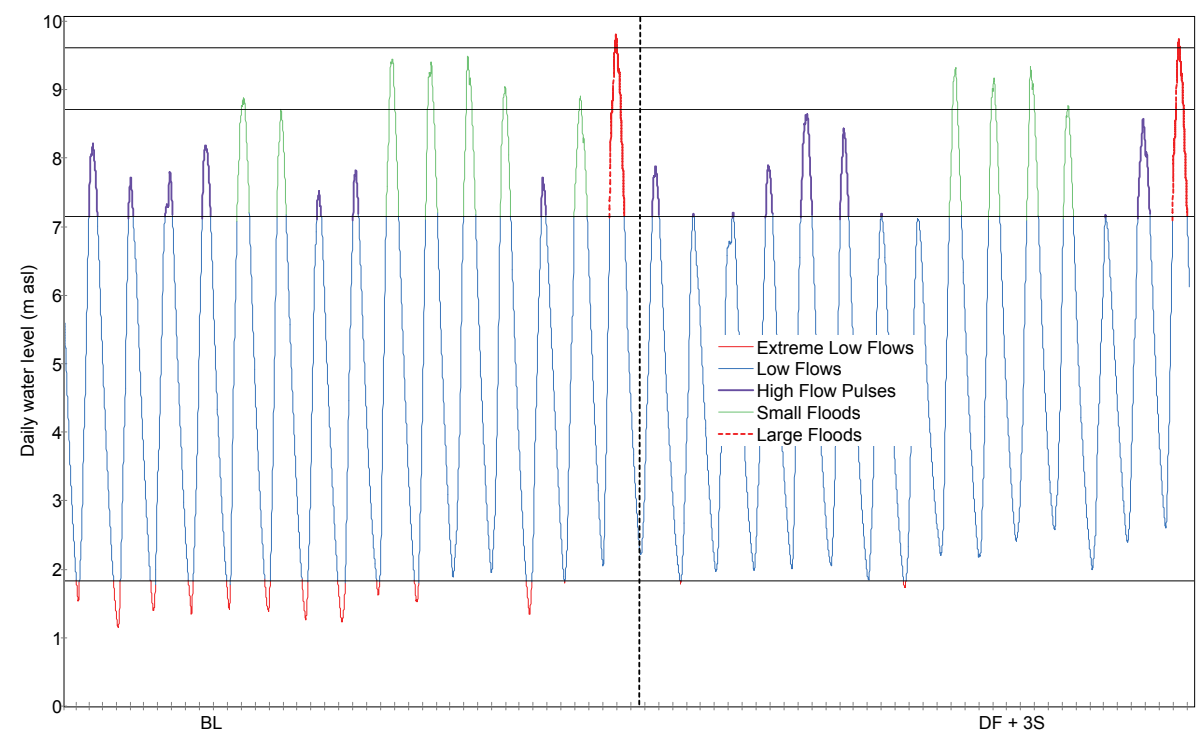

Figure 5. Comparison of daily water levels and environmental flow components between the baseline scenario (BL) and the combined effect of the definite future and the $3 \mathrm{~S}$ hydropower scenarios $(\mathrm{DF}+3 \mathrm{~S})$.

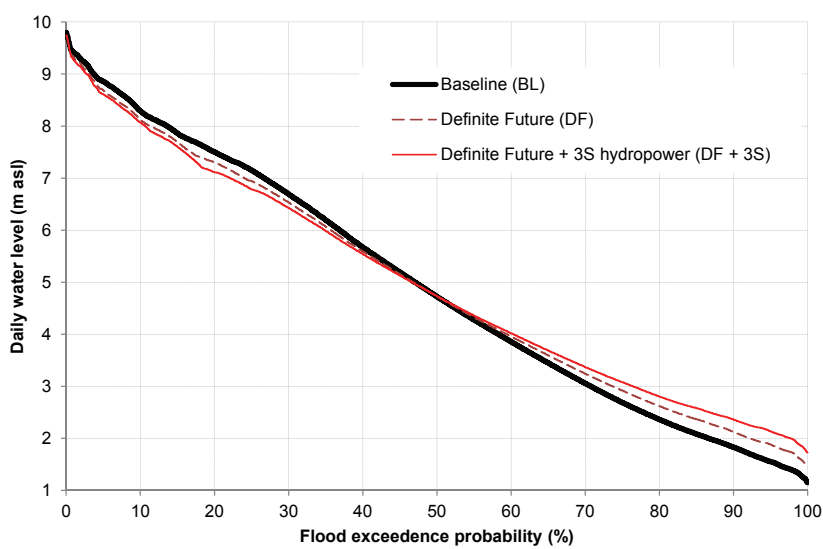

Figure 6. Exceedance probability plot of daily water levels. The greatest deviations are expected for water levels near the $20 \%$ exceedance level ( $\sim 7 \mathrm{~m}$ a.s.l.) and below the $70 \%$ exceedance level (less than $3 \mathrm{~m}$ a.s.1.).

\subsection{Cumulative hydrological alteration from the combined DF and 3S scenario}

The results of the simulations with the cumulative effects from the $\mathrm{DF}+3 \mathrm{~S}$ scenarios suggest that there could be a significant impact on the overall Tonle Sap flood regime. In terms of environmental flows, the cumulative impact of the $\mathrm{DF}+3 \mathrm{~S}$ scenario virtually eliminates all baseline extreme low flow conditions (Fig. 5): the frequency of these events is reduced from 11 to just one event in 15 years. Moreover, the BL scenario shows that high flow pulses and floods occur every single year, but that the frequency of these events decreases to two every three years.
Changes in the flood regime of the Tonle Sap are also reflected in the probability of water level exceedance (Fig. 6). Greatest deviations occur at exceedance levels above $70 \%$ : for instance, $2.36 \mathrm{~m}$ corresponds to the $80 \%$ exceedance level in BL, but this increases to 2.62 and $2.80 \mathrm{~m}$ for the DF and the DF $+3 \mathrm{~S}$ scenarios, respectively. Mild declines occur at the $20 \%$ exceedance level, but much milder changes were found for the greatest amplitude (and less frequent) events.

Hydropower development through the Mekong and its tributaries would alter multiple seasonal and annual hydrological parameters. The greatest alteration factors are expected to occur during the dry season months, with large alteration factors for monthly water levels during April and May, as well as other parameters including the 1-day, 3-day, 7-day, 30-day, and 90-day minima (Table 3). The DF scenario decreases the frequency of occurrence of the baseline dry season parameters by $40-60 \%$ ), but the addition of the $3 \mathrm{~S}$ hydropower network $(\mathrm{DF}+3 \mathrm{~S})$ results in alteration factors of $-100 \%$ for all of these parameters (meaning that they are expected to be altered every year). Factors of alteration in annual rates of water rise by $-33 \%$ and fall by $-20 \%$ for the DF scenario, but the magnitude of alteration factors increases to -83 and $-60 \%$ for the DF $+3 \mathrm{~S}$ scenario (Table 4 ).

\subsection{Changes in flood duration}

Both the DF and DF $+3 \mathrm{~S}$ scenarios could bring changes to the long-term spatial patterns of inundation throughout 51$60 \%$ of the Tonle Sap's floodplain (Fig. 7). In general, areas that are marginally inundated and areas that are permanently inundated are likely to expand, whereas areas that are seasonally inundated are likely to decrease. For instance, areas 


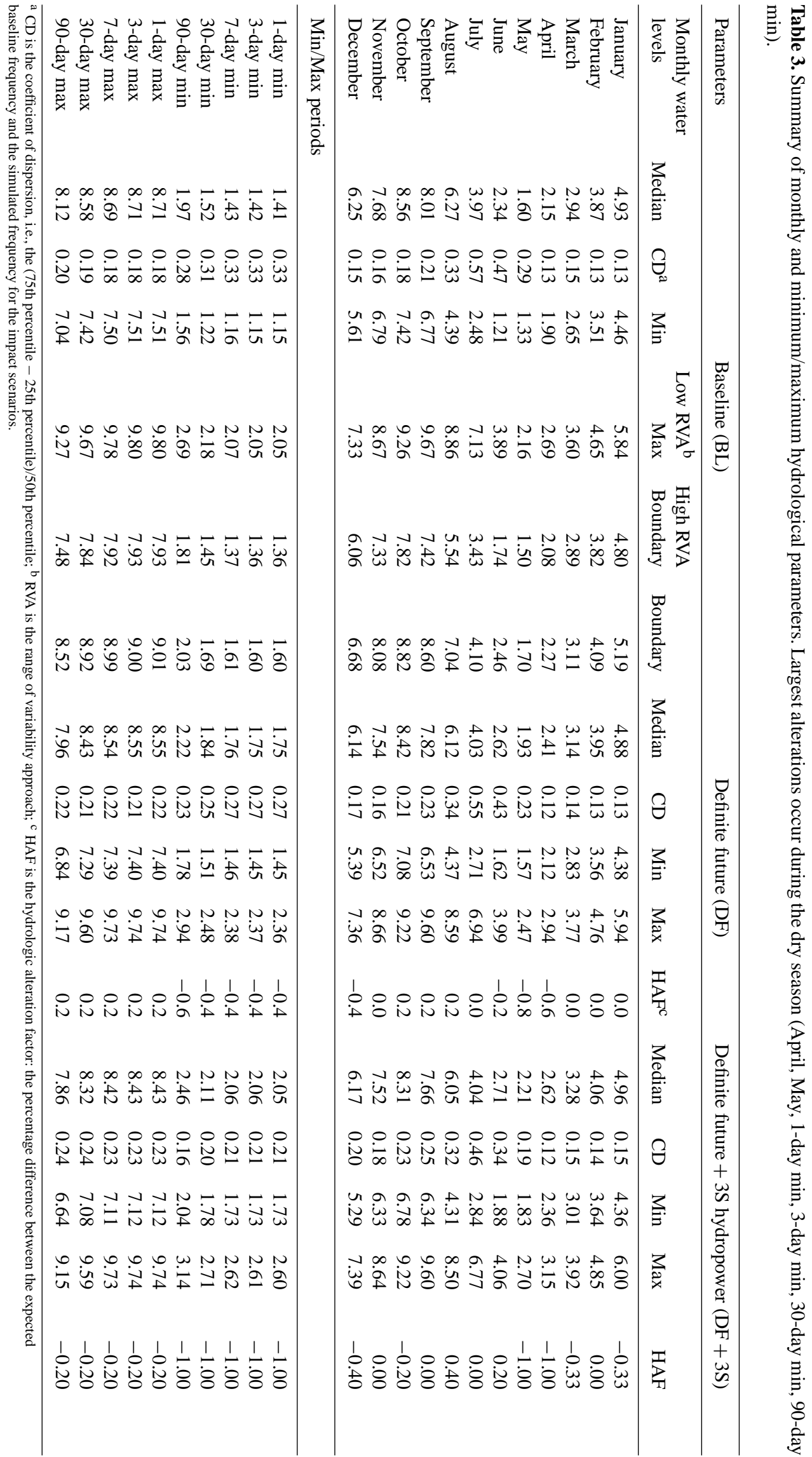




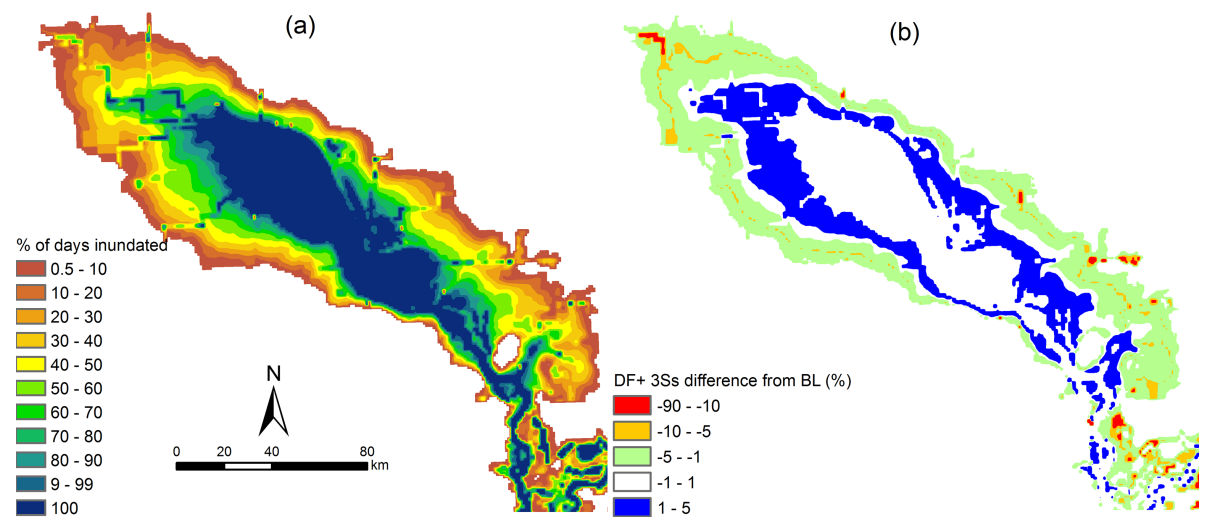

Figure 7. Maps representing the duration of flooding during the 15-year simulations: (a) shows the baseline (BL) flood duration map as percentage of total simulation time, while (b) shows the difference in flood duration between the combined definite future and $3 \mathrm{~S}$ hydropower scenarios (DF + 3S) and the baseline. Areas with an expected increase in flood duration are shown in blue, those where a decrease in flood duration is expected in the marginally inundated areas are shown in red, green and orange.

in the outermost class (inundated between $0.5-10 \%$ of the time) expand by $177 \mathrm{~km}^{2}(10.1 \%)$ and $283 \mathrm{~km}^{2}(16.1 \%)$ as a result of the DF and the DF $+3 \mathrm{~S}$ scenarios, respectively (Table 5). Moreover, the largest area shifts occur in areas inundated $90-100 \%$ of the time, which expand by $279 \mathrm{~km}^{2}$ $(5.7 \%)$ and $424 \mathrm{~km}^{2}(8.6 \%)$ as a result of the DF and the $\mathrm{DF}+3 \mathrm{~S}$ scenarios, respectively. On the contrary, classes inundated $20-90 \%$ shrink by $600 \mathrm{~km}^{2}$ and $994 \mathrm{~km}^{2}$ as a result of the DF and the DF $+3 \mathrm{~S}$ scenarios, respectively.

\section{Discussion}

This study presents an important contribution to the assessment of water resource management and development in the Mekong Basin. We have combined multiple hydrological modeling tools - all of which have been previously validated for the basin - and simulated the specific and combined impact of water resource development in two regions of great hydrological contribution to the whole basin. Piman et al. (2013a) had already showed that the scale of hydropower development in the $3 \mathrm{~S}$ was as large as the Lancang Jiang dam cascade. In this study, we have taken a step further and shown that the corresponding hydrological alterations from the $3 \mathrm{~S}$ hydropower projects are as large; perhaps more importantly, we have demonstrated that the cumulative effect of development in the Upper Mekong and the 3S will cause significant disruption to the inundation patterns of the Lower Mekong floodplains, in particular through an increase in dry season water levels as well as a reduction in water level rise and fall rates.

Our study (intentionally) assumed that there were no changes in rainfall-runoff from one simulation to the other in order to solely explore the issue of water regulation in tributary dams. This assumption, however, is not a complete representation of changes to the basin's hydrologi- cal cycle, as there are other key factors such as climate change (Kingston et al., 2011; Lauri et al., 2012), new irrigation schemes (Piman et al., 2013b), and land use/land cover changes (Costa-Cabral et al., 2007; Ishidaira et al., 2008) that alter rainfall-runoff characteristics and thus simultaneously affect the role of the $3 \mathrm{~S}$ on the Tonle Sap hydrology. As Ty et al. (2012) demonstrated for one of the $3 \mathrm{~S}$ rivers (Srepok), these other factors could also cause alterations, particularly a decrease in water availability during the dry season. Räsänen et al. (2014) showed that for the Sesan dam cascade in Vietnam irrigation water use during the dry season was relatively small compared to the increase in water flow caused by hydropower dams. In short, there is a great need for detailed modeling studies that take into account all of these major drivers of hydrological alterations.

This study demonstrated the use of IHA tools to assess the impact of future scenarios of water resources development. Although this tool has been previously used for simulated scenarios by Gao et al. (2009), their scenarios represented hypothetical reservoirs and dam operations, whereas our study represented existing and proposed projects based on actual design characteristics. IHA tools have been used in the Mekong by Ty et al. (2011) and Thompson et al. (2013), but their applications focused on climate change and excluded the Tonle Sap flooding characteristics. Our study has made a first attempt at quantifying environmental flows for the Tonle Sap using the simulations of baseline conditions, and our estimates could help guide environmental flow criteria based on the specific biological needs of this system. As the validation results showed, however, our model scheme had a slight tendency to overestimate historical dry season water levels; for that reason, the reported magnitude of water levels defining extreme low flows should be read with caution as they might be marginally higher than historical observations. We recommend that a closer analysis using long term observed water level records is carried out in order to more 


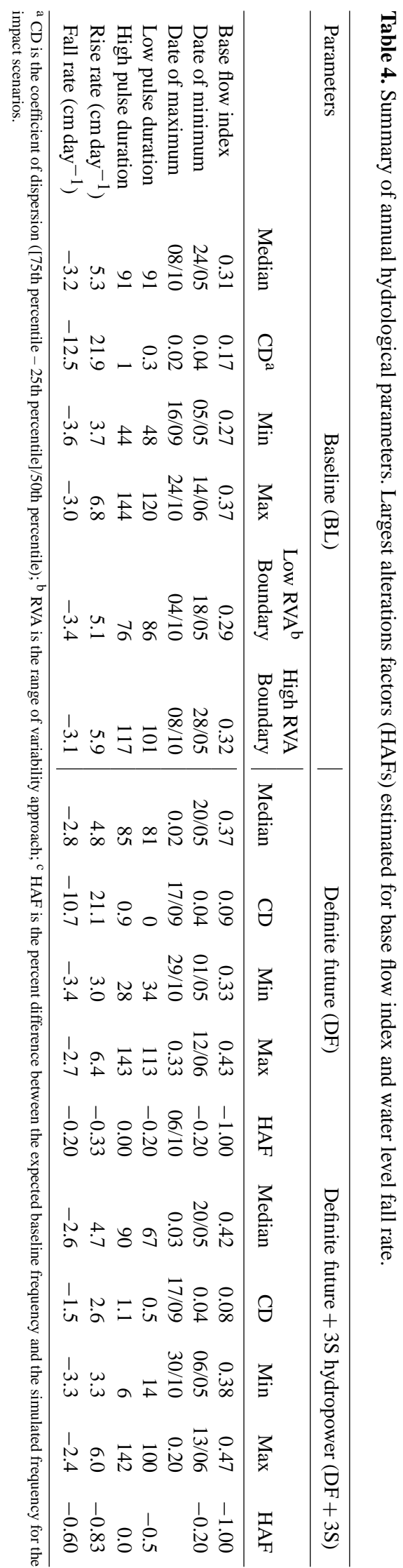

accurately define environmental flows and monitor ongoing alterations to these parameters.

Previous studies (Arias et al., 2012, 2014) also assessed the impacts of water resources development on water levels and flood duration at the Tonle Sap. These previous studies used three representative hydrological years (dry, average, and wet) in order to characterize multiyear variability. In general, it was found that hydrological alterations increased from wet to dry years. While the results from this study still support this trend in representative years, we found that over a longer time series only alterations to dry season water levels are expected to recur. Furthermore, our estimates of dry season water level alterations for the DF scenario are consistent with values previously reported (Arias et al., 2012; ICEM: 2010), whereas our estimates for the DF + 3S scenario ( +47 and $+61 \mathrm{~cm}$ for April and May, respectively) are considerably larger than any of the MRC future development scenarios previously reported (maximum of $+33 \mathrm{~cm}$ in April and $+39 \mathrm{~cm}$ in May; MRC, 2010). This difference highlights the significance of tributary dams to the hydrology of the entire basin and the importance of modeling their dimensions and operations in detail. Differences between the DF $+3 \mathrm{~S}$ scenario and previous estimates could also be partially attributed to water abstraction for irrigation during the dry season not considered in this study. A previous comparison of alterations from hydropower dams versus cumulative alterations of hydropower with irrigation did not show any major differences in the Lower Mekong (Piman et al., 2013b). In order to more comprehensively address this issue, further modeling studies in the Mekong should compare the effects of hydropower with irrigation development.

Significant hydrological alterations are expected in the Tonle Sap and the rest of the Lower Mekong floodplains if proposed hydropower development plans are acted upon. Ongoing trends and large economic incentives in the hydropower business tend to suggest that most of the hydropower potential will actually be exploited and dams will be built even in locations where there is a high risk of disruption to environmental flows. For instance, some of already operating dams in the 3S, such as the Yali Falls Dam (commissioned in 1994) on the Sesan River, were built without much consideration of transboundary environmental impacts and have in fact caused much damage in downstream Cambodia (Wyatt and Baird, 2007). Clear evidence of more recent trends are the Xayaburi Dam in the Mekong mainstream in Laos and the Lower Sesan 2 Dam at the confluence of the $3 \mathrm{~S}$ tributaries in Cambodia. Both of these dams have been already commissioned despite not only being highlighted as having potentially large ecological impacts in the scientific literature (e.g., ICEM, 2010; Ziv et al., 2012) but also after causing much controversy in the international media. Under a likely, "development as usual" scenario, the most feasible alternative to mitigate the disruptions in the Mekong of both existing and proposed dams consist of retrofitting controls to current design and operational practices in or- 
Table 5. Changes in spatial patterns of flooding in the Tonle Sap.

\begin{tabular}{lr|rr|rr}
\hline $\begin{array}{l}\text { Percent of days } \\
\text { inundated in } \\
\text { 15 years (\%) }\end{array}$ & $\begin{array}{r}\text { area } \\
\left(\mathrm{km}^{2}\right)\end{array}$ & $\begin{array}{r}\text { area } \\
\left(\mathrm{km}^{2}\right)\end{array}$ & $\begin{array}{r}\text { area change } \\
\text { from BL }(\%)\end{array}$ & $\begin{array}{r}\text { area } \\
\left(\mathrm{km}^{2}\right)\end{array}$ & $\begin{array}{r}\text { Area change } \\
\text { from BL (\%) }\end{array}$ \\
\cline { 2 - 6 } $0.5-10$ & 1758 & 1935 & 10.1 & 2042 & 16.1 \\
$10-20$ & 1417 & 1468 & 3.6 & 1582 & 11.7 \\
$20-30$ & 1421 & 1361 & -4.3 & 1275 & -10.3 \\
$30-40$ & 1667 & 1554 & -6.7 & 1480 & -11.2 \\
$40-50$ & 1533 & 1420 & -7.3 & 1349 & -12.0 \\
$50-60$ & 1391 & 1229 & -11.7 & 1018 & -26.8 \\
$60-70$ & 931 & 866 & -7.0 & 962 & 3.3 \\
$70-80$ & 949 & 941 & -0.9 & 885 & -6.7 \\
$80-90$ & 693 & 614 & -11.4 & 623 & -10.2 \\
$90-100$ & 4910 & 5188 & 5.7 & 5334 & 8.6 \\
\hline
\end{tabular}

der to optimize river services rather than just maximize hydropower generation. In other words, seasonal and diurnal operation rules should also aim at minimizing hydrological alterations downstream in addition to meeting electricity demands. From a hydrological point of view, run-of-the-river designs or operations in which power is gained primarily from flow volume and not elevation head would result in reduced environmental flow alterations. In addition to hydrological considerations, there are other aspects, such as sediment release and fish passage, that need to be implemented. These factors have not been widely considered in assessment studies in the Mekong (with the exception perhaps of Kummu et al., 2010; Ziv et al., 2012) and should therefore be the subject of further research.

\section{Conclusions}

This paper presented a study in which hydrological modeling and assessment tools were used to provide evidence of the expected hydrological alterations that hydropower development in the Lower Mekong tributaries could bring to the Tonle Sap. Hydrological alterations caused by dams in the $3 \mathrm{~S}$ were of similar magnitude as the DF scenario, which resembles water infrastructure development up to 2015 particularly driven by China's Lancang Jiang dam cascade in the Upper Mekong. DF plans in combination with the full development of the $3 \mathrm{~S}$ dam network will most likely cause significant and undocumented hydrological alterations to the Tonle Sap and the rest of the Lower Mekong floodplains. The most significant alterations are in terms of water levels during the dry season (April and May) and rates of water level rise and fall; these hydrological parameters are crucial for biological factors such as tree seed germination and fish migration, and therefore major ecological disruptions are likely to follow. Although there could be a decrease in wet season water levels in years of low flow from the Mekong, wet season disruptions are not recurrent in years of larger floods. Given the importance of the $3 \mathrm{~S}$ to the rest of the Lower Mekong, we recommend that more detailed studies of drivers of hydrological change in the $3 \mathrm{~S}$ are carried out, including irrigation, land use/land cover conversion, and climate change. Moreover, optimization of hydropower operations considering both electricity generation and environmental flows should be sought as a feasible alternative, and further studied and implemented in existing and proposed dams in this critical tributary.

Acknowledgements. Funding for the University of Canterbury was provided by John D. and Catherine T. MacArthur Foundation through a project entitled "Critical Basin at Risk: Assessing and managing ecosystem pressures from development and climate change in the $3 \mathrm{~S}$ basin". Comments from two reviewers were very helpful in improving the original manuscript.

Edited by: S. Uhlenbrook

\section{References}

Adamson, P. T., Rutherfurd, I. D., Peel, M. C., and Conlan, I. A.: The Hydrology of the Mekong River, in: The Mekong, 53-76, Academic Press, San Diego, available from: http:// www.sciencedirect.com/science/article/B9FBM-4Y59TWF-M/ 2/29840b78b5de4ee935ae707cd803a3b4, 2009.

Agostinho, A. A., Bonecker, C. C., and Gomes, L. C.: Effects of water quantity on connectivity: the case of the upper Paraná River floodplain, Ecohydrol. Hydrobiol., 9, 99-113, doi:10.2478/v10104-009-0040-x, 2009.

Arias, M. E., Cochrane, T. A., Kummu, M., Killeen, T. J., Piman, T., and Caruso, B. S.: Quantifying changes in flooding and habitats in the Tonle Sap Lake (Cambodia) caused by water infrastructure development and climate change in the Mekong Basin, J. Environ. Manage., 112, 53-66, 2012.

Arias, M. E., Cochrane, T. A., Kummu, M., Lauri, H., Koponen, J., Holtgrieve, G. W., and Piman, T.: Impacts of hydropower and 
climate change on drivers of ecological productivity of Southeast Asia's most important wetland, Ecol. Model., 272, 252-263, 2014.

Arias, M. E., Cochrane, T. A., Norton, D., Killeen, T. J., and Khon, P.: The flood pulse as the underlying driver of vegetation in the largest wetland and fishery of the Mekong Basin, AMBIO, 42, 864-876, doi:10.1007/s13280-013-0424-4, 2013.

Costa-Cabral, M. C., Richey, J. E., Goteti, G., Lettenmaier, D. P., Feldkötter, C., and Snidvongs, A.: Landscape structure and use, climate, and water movement in the Mekong River basin, Hydrol. Process., 22, 1731-1746, 2007.

Delgado, J. M., Merz, B., and Apel, H.: A climate-flood link for the lower Mekong River, Hydrol. Earth Syst. Sci., 16, 1533-1541, doi:10.5194/hess-16-1533-2012, 2012.

Dynesius, M. and Nilsson, C.: Fragmentation and Flow Regulation of River Systems in the Northern Third of the World, Science, 266, 753-762, doi:10.1126/science.266.5186.753, 1994.

FitzHugh, T. W.: EFCAM: A Method for Assessing Alteration of Environmental Flow Components. River Res. Appl. 30, 825-844, doi:10.1002/rra.2681, 2014.

Gao, Y., Vogel, R. M., Kroll, C. N., Poff, N. L., and Olden, J. D.: Development of representative indicators of hydrologic alteration, J. Hydrol., 374, 136-147, doi:10.1016/j.jhydrol.2009.06.009, 2009.

Grumbine, R. E., Dore, J., and Xu, J.: Mekong hydropower: drivers of change and governance challenges, Front. Ecol. Environ., 10, 91-98, doi:10.1890/110146, 2012.

Grumbine, R. E. and Xu, J.: Mekong Hydropower Development, Science, 332, 178-179, doi:10.1126/science.1200990, 2011.

ICEM: MRC Strategic Environmental Assessment of Hydropower on the Mekong mainstream, available at: http://icem.com.au/portfolio-items/ mrc-sea-of-hydropower-on-the-mekong-mainstream-reports-series/ (last access: 3 November 2013), 2010.

Ishidaira, H., Ishikawa, Y., Funada, S., and Takeuchi, K.: Estimating the evolution of vegetation cover and its hydrological impact in the Mekong River basin in the 21st century, Hydrol. Process., 22, 1395-1405, 2008.

Johnston, R. and Kummu, M.: Water Resource Models in the Mekong Basin: A Review, Water Resour. Manag., 26, 1-27, doi:10.1007/s11269-011-9925-8, 2011.

Kareiva, P. M.: Dam choices: Analyses for multiple needs, Proc. Natl. Acad. Sci., 109, 5553-5554, 2012.

Kingsford, R. T.: Ecological impacts of dams, water diversions and river management on floodplain wetlands in Australia, Austral Ecol., 25, 109-127, 2000.

Kingston, D. G., Thompson, J. R., and Kite, G.: Uncertainty in climate change projections of discharge for the Mekong River Basin, Hydrol. Earth Syst. Sci., 15, 1459-1471, doi:10.5194/hess-15-1459-2011, 2011.

Koponen, J., Kummu, M., Lauri, H., Virtanen, M., Inkala, A., and Sarkkula, J.: 3D Modelling User Guide, Final Report, MRC Information Knowledge Management Programme/Finnish Environment Institute (SYKE)/EIA Centre of Finland Ltd, 2010.

Kruskal, W. H. and Wallis, W. A.: Use of Ranks in OneCriterion Variance Analysis, J. Am. Stat. Assoc., 47, 583-621, doi:10.1080/01621459.1952.10483441, 1952.

Kummu, M., Lu, X. X., Wang, J. J., and Varis, O.: Basinwide sediment trapping efficiency of emerging reser- voirs along the Mekong, Geomorphology, 119, 181-197, doi:10.1016/j.geomorph.2010.03.018, 2010.

Kummu, M. and Sarkkula, J.: Impact of the Mekong River flow alteration on the Tonle Sap flood pulse, Ambio, 37, 185-192, 2008.

Kummu, M., Tes, S., Yin, S., Adamson, P., Józsa, J., Koponen, J., Richey, J., and Sarkkula, J.: Water balance analysis for the Tonle Sap lake - floodplain system, Hydrol. Process., 28, 1722-1733, doi:10.1002/hyp.9718, 2014.

Lauri, H., de Moel, H., Ward, P. J., Räsänen, T. A., Keskinen, M., and Kummu, M.: Future changes in Mekong River hydrology: impact of climate change and reservoir operation on discharge, Hydrol. Earth Syst. Sci., 16, 4603-4619, doi:10.5194/hess-164603-2012, 2012.

Lehner, B., Liermann, C. R., Revenga, C., Vörösmarty, C., Fekete, B., Crouzet, P., Döll, P., Endejan, M., Frenken, K., Magome, J., Nilsson, C., Robertson, J. C., Rödel, R., Sindorf, N., and Wisser, D.: High-resolution mapping of the world's reservoirs and dams for sustainable river-flow management, Front. Ecol. Environ., 9, 494-502, doi:10.1890/100125, 2011.

MRC: Impacts on the Tonle Sap Ecosystem, Basin Development Plan Programme, Phase 2. Mekong River Commission, Vientiane, Lao PDR, 2010.

MRC: Mekong River Commission Data Information Services Master Catalogue, available at: http://portal.mrcmekong.org/ master-catalogue, last access: 21 February 2014.

Nash, J. E. and Sutcliffe, J. V.: River flow forecasting through conceptual models part I - A discussion of principles, J. Hydrol., 10, 282-290, doi:10.1016/0022-1694(70)90255-6, 1970.

Nilsson, C. and Berggren, K.: Alterations of Riparian Ecosystems Caused by River Regulation, Bioscience, 50, 783-792, doi:10.1641/0006-3568(2000)050[0783:AORECB]2.0.CO;2, 2000.

Nilsson, C., Reidy, C. A., Dynesius, M., and Revenga, C.: Fragmentation and Flow Regulation of the World's Large River Systems, Science, 308, 405-408, doi:10.1126/science.1107887, 2005.

Petts, G. E.: Long-term Consequences of Upstream Impoundment, Environ. Conserv., 7, 325-332, doi:10.1017/S0376892900008183, 1980.

Piman, T., Cochrane, T. A., Arias, M. E., Green, A., and Dat, N. D.: Assessment of Flow Changes from Hydropower Development and Operations in Sekong, Sesan and Srepok Rivers of the Mekong Basin, J. Water Resour. Plan. Manag., 139, 723-732, doi:10.1061/(ASCE)WR.1943-5452.0000286, $2013 \mathrm{a}$.

Piman, T., Lennaerts, T., and Southalack, P.: Assessment of hydrological changes in the lower Mekong basin from basinwide development scenarios, Hydrol. Process., 27, 2115-2125, doi:10.1002/hyp.9764, 2013b.

Poff, N. L., Allan, J. D., Bain, M. B., Karr, J. R., Prestegaard, K. L., Richter, B. D., Sparks, R. E., and Stromberg, J. C.: The Natural Flow Regime, BioScience, 47, 769-784, doi:10.2307/1313099, 1997.

Poff, N. L., Olden, J. D., Merritt, D. M., and Pepin, D. M.: Homogenization of regional river dynamics by dams and global biodiversity implications, Proc. Natl. Acad. Sci., 104, 5732-5737, doi:10.1073/pnas.0609812104, 2007.

Poff, N. L. and Zimmermann, J. K. H.: Ecological responses to altered flow regimes: a literature review to inform the science and 
management of environmental flows, Freshw. Biol., 55, 194-205, doi:10.1111/j.1365-2427.2009.02272.x, 2010.

Räsänen, T. A., Koponen, J., Lauri, H., and Kummu, M.: Downstream Hydrological Impacts of Hydropower Development in the Upper Mekong Basin, Water Resour. Manaeg., 26, 3495-3513, doi:10.1007/s11269-012-0087-0, 2012.

Räsänen, T. A. and Kummu, M.: Spatiotemporal influences of ENSO on precipitation and flood pulse in the Mekong River Basin, J. Hydrol., 476, 154-168, doi:10.1016/j.jhydrol.2012.10.028, 2013.

Räsänen, T. A., Lehr, C., Mellin, I., Ward, P. J., and Kummu, M.: Palaeoclimatological perspective on river basin hydrometeorology: case of the Mekong Basin, Hydrol. Earth Syst. Sci., 17, 2069-2081, doi:10.5194/hess-17-2069-2013, 2013.

Räsänen, T., Joffre, O., Someth, P., Thanh, C., Keskinen, M., and Kummu, M.: Model-Based Assessment of Water, Food, and Energy Trade-Offs in a Cascade of Multipurpose Reservoirs: Case Study of the Sesan Tributary of the Mekong River, J. Water Resour. Plan. Manag., 05014007, 1-10, doi:10.1061/(ASCE)WR.1943-5452.0000459, 2014.

Richter, B. D., Baumgartner, J. V., Powell, J., and Braun, D. P.: A Method for Assessing Hydrologic Alteration within Ecosystems, Conserv. Biol., 10, 1163-1174, doi:10.1046/j.15231739.1996.10041163.x, 1996.

Richter, B. D., Baumgartner, J., Wigington, R., and Braun, D.: How much water does a river need?, Freshw. Biol., 37, 231-249, doi:10.1046/j.1365-2427.1997.00153.x, 1997.

Stone, R.: Mayhem on the Mekong, Science, 333, 814-818, doi:10.1126/science.333.6044.814, 2011.

The Nature Conservancy: Indicators of Hydrologic Alteration Version 7.1 User's Manual, available at: http://www.conservationgateway.org/ ConservationPractices/Freshwater/EnvironmentalFlows/ MethodsandTools/IndicatorsofHydrologicAlteration/Pages/ indicators-hydrologic-alt.aspx, (last access: 3 October 2013), 2009.
Thompson, J. R., Laizé, C. L. R., Green, A. J., Acreman, M. C., and Kingston, D. G.: Climate change uncertainty in environmental flows for the Mekong River, Hydrol. Sci. J., (Special Issue: Hydrological Science for Environmental Flows), 59, 935-954, doi:10.1080/02626667.2013.842074, 2013.

Ty, T. V., Sunada, K., and Ichikawa, Y.: A spatial impact assessment of human-induced intervention on hydrological regimes: a case study in the upper Srepok River basin, Central Highlands of Vietnam, Int. J. River Basin Manag., 9, 103-116, doi:10.1080/15715124.2011.595720, 2011.

Ty, T. V., Sunada, K., Ichikawa, Y., and Oishi, S.: Scenario-based Impact Assessment of Land Use/Cover and Climate Changes on Water Resources and Demand: A Case Study in the Srepok River Basin, Vietnam - Cambodia, Water Resour. Manag., 26, 13871407, doi:10.1007/s11269-011-9964-1, 2012.

Västilä, K., Kummu, M., Sangmanee, C., and Chinvanno, S.: Modelling climate change impacts on the flood pulse in the Lower Mekong floodplains, J. Water Clim. Change, 01, 67-86, doi:10.2166/wcc.2010.008, 2010.

Walling, D. E.: The Sediment Load of the Mekong River, in The Mekong, 113-142, Academic Press, San Diego, 2009.

WB: Modelled Observations on Development Scenarios in the Lower Mekong Basin, World Bank, Vientiane, Lao PDR, 2004.

Wyatt, A. B. and Baird, I. G.: Transboundary Impact Assessment in the Sesan River Basin: The Case of the Yali Falls Dam, Int. J. Water Resour. D, 23, 427-442, 2007.

Ziv, G., Baran, E., Nam, S., Rodriguez-Iturbe, I., and Levin, S. A.: Trading-off fish biodiversity, food security, and hydropower in the Mekong River Basin, Proc. Natl. Acad. Sci., 109, 5609-5614, doi:10.1073/pnas.1201423109, 2012. 